\title{
BACTERIOLOGICAL AND SEROLOGICAL STUDY OF CHRONIC PROSTATITIS PATIENTS*
}

\author{
BY \\ Z. MAGED AND H. KHAFAGA \\ From the Departments of Bacteriology and Venereology, Faculty of Medicine, Ain Shams University, \\ Cairo, U.A.R.
}

Chronic prostatitis is not uncommon in men over 50 years, though it can occur at any age. The organisms most commonly isolated from the prostatic secretion are staphylococci, streptococci, coliform bacilli, and diphtheroids. Nickel (1930) in 3,500 cultures found streptococci in 38 per cent., staphylococci in 54 per cent., bacilli in 24 per cent., and diphtheroids and diplobacilli in 9 per cent. Ritter and Lippow (1938) studied 131 cases and isolated streptococci in 54 , staphylococci in 27 , other cocci in 18 , colon bacilli in four, diphtheroids in 22 , and no organisms in six. Cumming and Chittenden (1938), in a series of 175 cases, isolated staphylococci in 50 per cent., colon bacilli in 30 per cent., streptococci in 5 per cent., gonococci in 5 per cent., diphtheroids in 2 per cent., and no organisms in 8 per cent.

The role of $N$. gonorrhoeae is not agreed upon. Cumming and Chittenden stated that at least 75 per cent. of patients with prostatic infection have had gonorrhoea in the recent or remote past, but Wesson (1938) remarked that the incrimination of gonococci as a common cause of prostatitis was questionable; in his opinion non-specific prostatitis was generally present at the time of contraction of gonorrhoeal urethritis, and this antecedent infection persisted after the gonococci had disappeared. Kretschmer, Berkey, Heckel, and Ockuly (1937) found only 24 cases of gonorrhoeal infection in 1,000 patients with chronic prostatitis. According to Pelouze (1939) 95 per cent. of cases of chronic prostatitis were secondary to infections elsewhere in the body, the most common primary foci being the teeth and tonsils; he also stated that 35 per cent. of all men over 50 years have chronic prostatitis and that in 95 per cent. dental infection was the primary focus of the prostatic infection. The infection may be related to prolonged congestion which may cause a fertile field for bacterial invasion.

Chronic urethral infections may easily pass directly into the prostatic ducts. Invasion of the

\footnotetext{
* Received for publication December 15, 1964.
}

prostate may also occur from lymphatics, from adjacent organs or from infections higher in the urinary tract with infected urine.

Since urinary tract infections and complications are common in Egypt through bilharziasis, one would expect that the most common route of invasion of the prostate would be the urinary tract. Knowledge of the route of invasion is important in treating inflammation and preventing its recurrence.

The aim of the present work was to study patients suffering from chronic bacterial prostatitis to discover the incidence of bacteria in bacterial prostatitis, and to evaluate the urinary tract as the possible route of invasion of the prostate.

Because of the high incidence of staphylococcal infections without associated urinary tract infection, a group of these patients were subjected to:

(a) A bacteriological study of the staphylococci causing prostatitis and their sensitivity to penicillin.

(b) A serological study of the sera and prostatic fluids for the presence of antibodies to the strain of staphylococcus isolated.

(c) A bacteriological and serological follow-up of these patients was attempted.

\section{Material and Methods}

150 patients with chronic bacterial prostatitis attending the out-patient clinic of Demerdash Hospital were studied and those were included whose prostatic secretions showed signs of inflammation with pus counts above ten per high-power field, the bacteria giving cultures of more than twenty colonies per Petri dish.

A control group of twenty normal men between 20 and 40 years of age were examined in the same way as the patients.

From all patients and normal controls the following specimens were collected aseptically:

(1) Urine before and after prostatic massage.

(2) Prostatic secretion.

(3) $5 \mathrm{ml}$. blood drawn before massage. 
Samples of urine and prostatic secretion were collected in the following manner. The urinary meatus was washed with soap and,water and sterilized by Dettol. The first portion of urine voided was discarded and a midstream sample was collected in a sterile $8-\mathrm{oz}$. bottle. The urinary meatus was then again sterilized with Dettol and prostatic massage was performed. The first drop of the prostatic secretion was discarded and that following was collected in a sterile bottle. A second midstream specimen of urine after massage was then collected in the same manner.

Prostatic Secretions.-These were studied in a fresh unstained preparation for the number of pus cells and the presence of Trichomonas vaginalis.

Smears from prostatic secretion stained by Gram's method were examined for the presence of microorganisms, especially gonococci.

Finally, the prostatic secretion was cultured on 5 per cent. blood agar prepared from infusion broth and on BGL medium (Tawil and El Kholy, 1962) and incubated aerobically at $37^{\circ} \mathrm{C}$.

Urine.-The specimens were centrifuged and the deposit studied microscopically as for the prostatic secretion and cultured.

Blood.-For agglutination tests the following procedure was followed. The specimens were allowed to clot and the serum separated. The prostatic secretion was centrifuged and the supernatant fluid aspirated. Serum specimens were titrated by a tube dilution method starting with a dilution of $1 / 5$. The prostatic secretion of the patient's group was titrated against the corresponding infecting organism by the tube method, starting with a dilution of $1 / 5$. As each specimen of the prostatic secretion of the normal control group was titrated against the sixty staphylococcal strains isolated from the patients, and as the volume of the prostatic secretion ranged from 1.5 to $0.5 \mathrm{ml}$., the tube agglutination method could not be used and a slide agglutination test was used instead, starting with a dilution of $1 / 10$.

Tube Agglutination.-The serum and prostatic fluid was diluted $1 / 2.5$, and serial 2 -fold dilutions in saline were prepared up to $1 / 5,120$. From each dilution starting at $1 / 2.5,0.2 \mathrm{ml}$. were transferred to a Dreyer tube. An equal volume of the bacterial suspension was then added. A control tube containing bacterial suspension and $0.2 \mathrm{ml}$. saline was included in each test. Tests were incubated at $55^{\circ} \mathrm{C}$. for 4 hours, and the results read after incubation overnight at room temperature. The bacterial suspensions used were prepared from cultures on nutrient agar suspended in saline and heated at $65^{\circ} \mathrm{C}$. for 30 minutes. The density of the suspensions was 2,000 million organisms $/ \mathrm{ml}$. approximately. All the strains tested were smooth and none gave autoagglutination.

Slide Agglutination.-The prostatic secretion of the control group was diluted $1 / 10$ and from this serial 2 -fold dilutions in saline were prepared. A loopful of the growth of staphylococcus on nutrient agar was emulsified in saline and when homogenized one loopful was taken and placed on a clean slide. To this was added one drop of the prostatic secretion taken by a Pasteur pipette and the result well mixed. The slide was then rocked gently for 33 minutes and observed by a hand lens.

The slide agglutination test was compared with the tube agglutination test with five prostatic secretions taken from chronic prostatitis patients. Both tests gave the same results in four cases and in one case the slide test gave a lower titre (a difference of one tube only). The tube method was preferred whenever amounts of material allowed, as it was easier to read and gave a sharper end-point.

The organisms were tested for their sensitivity to penicillin by the disk method, using 10 units penicillin per disk.

\section{Results and Discussion}

Patients with Prostatitis.-From the total of 150 cases that gave positive bacteriological findings, the organisms isolated and their incidence were as shown in Table I, which shows that staphylococci were found in 127 cases ( 84 per cent.) and were the sole infecting organism in 88 cases ( $58 \cdot 7$ per cent.).

TABLE I

BACTERIA ISOLATED FROM PROSTATIC SECRETION OF PATIENTS WITH CHRONIC PROSTATITIS

\begin{tabular}{|c|c|c|c|c|}
\hline \multicolumn{3}{|c|}{ Organism } & $\begin{array}{l}\text { No. of } \\
\text { Cases }\end{array}$ & $\begin{array}{c}\text { Per- } \\
\text { centage }\end{array}$ \\
\hline $\begin{array}{l}\text { Staphylococci } \\
\text { Enterococci .. } \\
\text { Diphtheroids } \\
B . \text { coli } \\
\text { Staphylococci and } \\
\text { Staphylococci and } \\
B \text {. coli } \text { and Entero } \\
B \text {. coli } \text { and Diphth } \\
\text { Staphylococci and } \\
\text { Staphylococci and }\end{array}$ & $\begin{array}{l}\ldots \\
\ldots \\
\ldots \\
\text { a } \\
\text { Enterococci } \\
\text { d Diphtheroids } \\
\text { ococci } \quad . \\
\text { heroids . } \\
\text { d Gonococci } \\
\text { Trichomonas va }\end{array}$ & $\begin{array}{ll}\ldots & \ldots \\
\ldots & \ldots \\
\ldots & \ldots \\
\ldots & \ldots \\
\ldots & \ldots \\
\ldots & \ldots \\
\ldots & \ldots \\
\text { vaginalis. } & \ldots\end{array}$ & $\begin{array}{r}88 \\
11 \\
4 \\
4 \\
23 \\
13 \\
2 \\
1 \\
1 \\
3\end{array}$ & $\begin{array}{c}58 \cdot 7 \\
7 \cdot 3 \\
2 \cdot 7 \\
2 \cdot 7 \\
15 \cdot 3 \\
8 \cdot 7 \\
1 \cdot 3 \\
0 \cdot 65 \\
0 \cdot 65 \\
2 \cdot 0\end{array}$ \\
\hline
\end{tabular}

The incidence of organisms isolated from this group of patients with chronic bacterial prostatitis differs markedly from that found in a similar study carried out in this department on urinary tract infections (Shaheen, Maged, and Maged, 1963) in which the order of incidence of bacteria was coliform bacilli $26 \cdot 5$ per cent., Ps. pyocyanea $23 \cdot 5$ per cent., $B$. proteus $17 \cdot 6$ per cent., staphylococci 23.5 per cent., and diphtheroids 8.8 per cent. If invasion of the prostate came from infections of the urinary tract one would expect a similar distribution of organisms in the two infections.

The 127 strains of staphylococci were studied for pathogenicity using the following tests: pigment production; haemolysin activity, mannite fermentation, and coagulase production (Topley and Wilson, 1955). Bacteriophage typing was not done. The results are seen in Table II (overleaf), which shows that 52 strains gave a golden-yellow pigment and were designated Staph. aureus, while the remaining 75 strains gave a porcelain white growth (i.e. Staph. 
albus). All the strains gave positive results in one or more of the other tests, and were therefore considered to be albus variants of the aureus type (i.e. Staph. pyogenes).

TABLE II

RESULTS OF TESTS DONE ON THE STAPHYLOCOCCI ISOLATED FROM CASES OF CHRONIC PROSTATITIS

\begin{tabular}{|c|c|c|c|c|}
\hline $\begin{array}{l}\text { Number of } \\
\text { Strains }\end{array}$ & Pigment & $\begin{array}{c}\text { Haemolysin } \\
\text { Activity }\end{array}$ & $\begin{array}{l}\text { Coagulase } \\
\text { Production }\end{array}$ & $\begin{array}{c}\text { Mannite } \\
\text { Fermentation }\end{array}$ \\
\hline $\begin{array}{r}40 \\
8 \\
3 \\
1 \\
29 \\
24 \\
11 \\
2 \\
3 \\
3 \\
3\end{array}$ & $\begin{array}{l}\text { Golden } \\
\text { Golden } \\
\text { Golden } \\
\text { Golden } \\
\text { White } \\
\text { White } \\
\text { White } \\
\text { White } \\
\text { White } \\
\text { White } \\
\text { White }\end{array}$ & $\begin{array}{l}\text { Present } \\
\text { Present } \\
\text { Present } \\
\text { Present } \\
\text { Present } \\
\text { Present } \\
\text { Absent } \\
\text { Absent } \\
\text { Absent } \\
\text { Absent } \\
\text { Present }\end{array}$ & $\begin{array}{l}\text { Present } \\
\text { Present } \\
\text { Present } \\
\text { Absent } \\
\text { Present } \\
\text { Present } \\
\text { Present } \\
\text { Present } \\
\text { Present } \\
\text { Present } \\
\text { Absent }\end{array}$ & $\begin{array}{l}\text { Acid } \\
\text { Late } \\
\text { Absent } \\
\text { Acid } \\
\text { Acid } \\
\text { Late } \\
\text { Acid } \\
\text { Acid } \\
\text { Late } \\
\text { Absent } \\
\text { Present }\end{array}$ \\
\hline
\end{tabular}

Gonococci were isolated by culture of the prostatic secretion in one case only which was negative by direct stained smear.

Diphtheroids were isolated from the prostatic secretion of eighteen patients. In four they were the sole infecting organism and in fourteen they were present with other infective agents. The stained films of the prostatic secretion showed the presence of diphtheroids in all the former group and in eight of the latter.

Trichomonas vaginalis was present in three cases associated with staphylococci, and in five other cases not included in this series because the prostatic secretions were bacteriologically sterile on culture. Table III gives a detailed description of the findings in these eight patients. Though the number of patients is too small to make deductions, the following points should be noted:

(1) Infection of the prostate with Trichomonas is not necessarily associated with infection of the urinary tract. In seven out of eight patients Trichomonas was present in the prostatic secretion only, but in Case 8 it was present in the urine as well. This finding could agree with our observation that the urinary tract is not the main route of prostatic infection.
(2) In Cases 6 to 8 Trichomonas was present together with staphylococci. Cultures of the staphylococci in the prostatic or urinary specimens that showed Trichomonas appeared after 24 hours but within 48 to 72 hours. The coincidence of the late appearance of growth of staphylococci in cases of Trichomonas infection, together with the comparatively small number of cases of staphylococcal infection in the presence of Trichomonas could be ascribed to a slight bacteriostatic effect of Trichomonas on this organism which should be investigated.

None of the specimens of urine examined showed Bilharzia ova. A past history of bilharziasis of the urinary tract and its successful treatment was given by 20 patients $(13 \cdot 3$ per cent.).

The urine samples taken before massage showed a high pus count in only nine patients ( 6 per cent.). The organisms isolated from the urine were the same as those isolated from the prostatic secretion (B. coli in three cases, $B$. coli and enterococci in two, and staphylococci in four).

The other 94 per cent. of cases of chronic bacterial prostatitis did not show evidence of urinary tract infection. This, together with the difference in the frequency of distribution of causative organisms in both conditions, suggests that the urinary tract is not the main route of chronic bacterial infection of the prostate.

Control Group.-None of the twenty urine specimens taken before massage and none of the prostatic secretion specimens taken from the normal controls showed evidence of inflammation. The pus count of the urine ranged from 0 to 3 and that of the prostatic secretions from 1 to 6 per high-power field. The cultures were negative in all the prostatic specimens and in eighteen of the urine specimens. In two urine specimens a few colonies of diphtheroids (less than three per Petri dish) were present; these were considered as contaminants from the urethra.

\section{Penicillin Sensitivity Tests}

Of the 127 staphylococcus strains tested, $34(26 \cdot 8$ per cent.) were found to be sensitive to 10 units

TABLE III

FINDINGS IN EIGHT PATIENTS WITH TRICHOMONAL PROSTATITIS

\begin{tabular}{|c|c|c|c|c|c|c|c|}
\hline \multirow{2}{*}{$\begin{array}{l}\text { Case } \\
\text { No. }\end{array}$} & \multicolumn{3}{|c|}{ Pus Count } & \multicolumn{2}{|c|}{ Trichomonas } & \multicolumn{2}{|c|}{ Culture } \\
\hline & $\begin{array}{c}\text { Urine } \\
\text { before Massage }\end{array}$ & $\begin{array}{l}\text { Prostatic } \\
\text { Secretion }\end{array}$ & $\begin{array}{c}\text { Urine } \\
\text { after Massage }\end{array}$ & $\begin{array}{l}\text { Prostatic } \\
\text { Secretion }\end{array}$ & $\begin{array}{c}\text { Urine } \\
\text { before Massage }\end{array}$ & $\begin{array}{l}\text { Prostatic } \\
\text { Secretion }\end{array}$ & Urine \\
\hline $\begin{array}{l}1 \\
2 \\
3 \\
4 \\
5\end{array}$ & $\begin{array}{l}2-4 \\
0-2 \\
0-4 \\
3-6 \\
0-3\end{array}$ & $\begin{array}{l}55-70 \\
12-20 \\
30-45 \\
45-60 \\
25-40\end{array}$ & $\begin{array}{r}12-20 \\
2-5 \\
8-15 \\
10-18 \\
6-12\end{array}$ & $\begin{array}{l}\text { Present } \\
\text { Present } \\
\text { Present } \\
\text { Present } \\
\text { Present }\end{array}$ & $\begin{array}{l}\text { Absent } \\
\text { Absent } \\
\text { Absent } \\
\text { Absent } \\
\text { Absent }\end{array}$ & $\begin{array}{l}\text { Sterile } \\
\text { Sterile } \\
\text { Sterile } \\
\text { Sterile } \\
\text { Sterile }\end{array}$ & $\begin{array}{l}\text { Sterile } \\
\text { Sterile } \\
\text { Sterile } \\
\text { Sterile } \\
\text { Sterile }\end{array}$ \\
\hline $\begin{array}{l}6 \\
7 \\
8\end{array}$ & $\begin{array}{r}10-16 \\
3-5 \\
50-70\end{array}$ & $\begin{array}{c}100 \\
30-60 \\
100\end{array}$ & $\begin{array}{r}15-25 \\
8-15 \\
60-80\end{array}$ & $\begin{array}{l}\text { Present } \\
\text { Present } \\
\text { Present }\end{array}$ & $\begin{array}{l}\text { Absent } \\
\text { Absent } \\
\text { Present }\end{array}$ & $\begin{array}{l}\text { Staph. } \\
\text { Staph. } \\
\text { Staph. }\end{array}$ & $\begin{array}{l}\text { Staph. } \\
\text { Sterile } \\
\text { Staph. }\end{array}$ \\
\hline
\end{tabular}


penicillin. The other 93 strains were resistant to penicillin.

\section{Inflammatory Response}

The patients were classified in two groups according to the pus count in the prostatic secretion. Group I had a pus count of 10 to 30 per high-power field, and group II more than 30 per high-power field or a lower count but with many pus clumps. The organisms isolated and their incidence did not differ significantly in the two groups.

Serological Results.--Sixty patients with staphylococcal infection were studied for the presence of agglutinins towards their infecting strain in both blood and prostatic secretion.

The twenty normal controls were studied for the presence of agglutinins in their blood and prostatic secretion towards the sixty staphylococcal strains isolated from the patients. Their sera contained agglutinins to the sixty strains, the titres ranging from $1: 5$ to $1: 40$. As the amount of the prostatic secretion was limited, titrations were started at a dilution of $1: 10$. No agglutinins were found to these organisms in the normal prostatic secretions.

All the sera and prostatic secretions of the patients contained agglutinins to the infecting strain of staphylococcus in all the sixty patients.

The prostatic titres ranged from 1:40 to $1: 640$ and the blood titres from $1: 10$ to $1: 640$. The results are shown in Table IV, which demonstrates that the body responds to infection of the prostate by the production of antibodies in both the blood and the prostatic secretion.

Such serum agglutinins are not those that are normally present; the titres are distinctly higher than in the control group and continued to rise in the ten cases that could be followed up.

The agglutinins found in the prostatic secretion may be derived from circulating antibodies through the exudation of plasma from inflamed and damaged tissues, or from cells within the organ (i.e. local production). That exudation is not the only factor here is clear from the high percentage of cases in which the titre is higher in the prostatic secretion than in the blood ( $43 \cdot 3$ per cent.) or equals that in the blood ( $36 \cdot 7$ per cent.). These data are shown in Table V.

\section{TABLE V}

RELATION BETWEEN PROSTATIC AND BLOOD TITRES IN THE TOTAL NUMBER OF PATIENTS

\begin{tabular}{|c|c|c|c|c|c|c|c|}
\hline \multicolumn{6}{|c|}{ Relation of Prostatic Titre to Blood Titre } & \multirow{2}{*}{$\begin{array}{c}\begin{array}{c}\text { No. of } \\
\text { Patients }\end{array} \\
26 \\
22 \\
12\end{array}$} & \multirow{2}{*}{$\begin{array}{c}\text { Percentage } \\
43 \cdot 3 \\
36 \cdot 7 \\
20 \cdot 0\end{array}$} \\
\hline $\begin{array}{l}\text { Higher } \\
\text { Equal } \\
\text { Lower }\end{array}$ & $\begin{array}{l}\ldots \\
\cdots\end{array}$ & $\begin{array}{l}\ldots \\
\cdots \\
\ldots\end{array}$ & $\begin{array}{l}\ldots \\
\cdots \\
\ldots\end{array}$ & $\begin{array}{c}\cdots \\
\cdots\end{array}$ & $\begin{array}{l}\cdots \\
\cdots \\
\cdots\end{array}$ & & \\
\hline
\end{tabular}

In simple exudation the blood titre is expected to

TABLE IV

RELATION OF AGgLUTININS PRESENT IN PROSTATIC SECRETION TO BLOOD TITRE, BY NUMBER OF PUS CELLS

\begin{tabular}{|c|c|c|c|c|c|c|c|c|c|c|}
\hline \multirow{4}{*}{$\begin{array}{c}\text { Relation of } \\
\text { Prostatic } \\
\text { Titre to } \\
\text { Blood } \\
\text { Titre }\end{array}$} & \multicolumn{10}{|c|}{ Number of Pus Cells } \\
\hline & \multicolumn{5}{|c|}{ Group I (40 Patients) } & \multicolumn{5}{|c|}{ Group II ( 20 patients) } \\
\hline & \multirow{2}{*}{$\begin{array}{l}\text { No. of } \\
\text { Patients }\end{array}$} & \multicolumn{2}{|c|}{ Titre } & \multirow{2}{*}{ Ratio } & \multirow{2}{*}{ Per cent. } & \multirow{2}{*}{$\begin{array}{l}\text { No. of } \\
\text { Patients }\end{array}$} & \multicolumn{2}{|c|}{ Titre } & \multirow{2}{*}{ Ratio } & \multirow{2}{*}{ Per cent. } \\
\hline & & Prostatic & Blood & & & & Prostatic & Blood & & \\
\hline Lower & $\left.\begin{array}{l}1 \\
1\end{array}\right\}^{2}$ & $\begin{array}{l}20 \\
20\end{array}$ & $\begin{array}{r}80 \\
320\end{array}$ & $\begin{array}{l}1: 4 \\
1: 16\end{array}$ & 5 & $\left.\begin{array}{l}3 \\
3 \\
2 \\
1 \\
1\end{array}\right\} 10$ & $\begin{array}{l}20 \\
20 \\
40 \\
80 \\
10\end{array}$ & $\begin{array}{r}40 \\
80 \\
160 \\
320 \\
160\end{array}$ & $\begin{array}{l}1: 2 \\
1: 4 \\
1: 16\end{array}$ & 50 \\
\hline Equal & $\left.\begin{array}{l}1 \\
1 \\
1 \\
2 \\
5 \\
4\end{array}\right\}$ & $\begin{array}{r}20 \\
40 \\
80 \\
160 \\
320 \\
640\end{array}$ & $\begin{array}{r}20 \\
40 \\
80 \\
160 \\
320 \\
640\end{array}$ & $1: 1$ & 35 & $\left.\begin{array}{l}1 \\
1 \\
3 \\
1 \\
2\end{array}\right\}$ & $\begin{array}{r}40 \\
80 \\
160 \\
320 \\
640\end{array}$ & $\begin{array}{r}40 \\
80 \\
160 \\
320 \\
640\end{array}$ & $1: 1$ & 40 \\
\hline Higher & $\left.\begin{array}{r}1 \\
1 \\
2 \\
4 \\
1 \\
1 \\
3 \\
1 \\
2 \\
1 \\
3 \\
3 \\
1\end{array}\right\} 24$ & $\begin{array}{r}640 \\
320 \\
160 \\
80 \\
40 \\
640 \\
320 \\
640 \\
160 \\
40 \\
320 \\
80 \\
20\end{array}$ & $\begin{array}{r}80 \\
40 \\
40 \\
20 \\
10 \\
160 \\
80 \\
320 \\
80 \\
20 \\
160 \\
40 \\
0\end{array}$ & $\begin{array}{l}8: 1 \\
4: 1\end{array}$ & 60 & $1\}^{2}$ & $\begin{array}{l}80 \\
80\end{array}$ & $\begin{array}{l}40 \\
20\end{array}$ & $\begin{array}{l}2: 1 \\
4: 1\end{array}$ & 10 \\
\hline
\end{tabular}


be higher than in the prostatic secretion; moreover, no such antibodies were found in the prostatic secretion of the normal controls.

The presence of antibodies to the infecting organisms in the prostatic secretion agrees with previous findings of other authors in fluids taken from various infected organs. Zammit (1906) found agglutinins for $\mathrm{Br}$. melitensis in the milk of infected goats. Stoker and Marmion (1952) found agglutinins for $R$. burneti in the whey of infected cattle. Dysentery stools were found by Davies (1922) to contain agglutinins for dysentery bacilli. Burrows, Elliott, and Havens (1947) found agglutinins for cholera vibrios in the faeces of infected guinea-pigs. The urine of human beings and dogs with leptospiral infections were found to contain agglutinins for the infecting species (van der Hoeden, 1936).

The local production of antibodies at the injection site of antigen or at sites of antigen deposition in the tissues has also been demonstrated by many workers. Kabat, Moore, and Landow (1942) have shown that the spinal fluid of patients with neurosyphilis, who have demonstrable Wassermann antibodies in the spinal fluid when these are absent from the serum, may contain percentages of gamma globulin higher than that in the serum. They concluded that these antibodies were formed in the central nervous system. Schlesinger (1949), working with equine encephalomyelitis virus in mice, found that, when systemically vaccinated mice were challenged intracerebrally, a secondary response occurred in the central nervous system while the serum antibody remained low. Barksdale and Ghoda (1951) found in patients with dysentery caused by Sh. flexneri or Sh. sonnei that antibodies appeared earlier in the faeces than in the blood and that there were also qualitative differences in the antibodies in these localities, i.e. antibodies to phase I and II Sonne antigen occurred in the faeces and to phase I alone in the serum. Koshland and Burrows (1950) investigated the quantitative relationship between the serum and faecal antibody response in guinea-pigs immunized with cholera vaccine and concluded that faecal antibodies behaved independently of serum antibodies and were therefore not derived from the latter. Archer and Miller (1952) and Naylor and Caldwell (1953) suggested that antibodies in the urine of urinary enteric carriers were produced within the urinary tract.

Table IV shows the relationship between the prostatic and blood titres in the two groups of patients. Though the groups are not statistically identical, marked difference is noted between them. In Group I, the prostatic titre equals the blood titre in 35 per cent., is higher than the blood titre in 60 per cent., and is lower than the blood titre in 5 per cent. The corresponding percentages in Group II are 40, 10 , and 50. Group I includes patients with prostatic secretions with pus counts from ten to 30/high-power fields, and Group II those with pus counts higher than thirty/high-power fields or a lower pus count but many pus clumps. The difference between the two groups may be due to specific absorption of antibodies by organisms in the prostatic secretion which tends to lower the titre against the species carried, or it may be that severe inflammation destroys any local antibody producing cells, or the difference may be due to immune paralysis due to antigen excess.

Follow-up.-Ten patients were examined about 6 weeks later. In eight of them the prostatic secretions were found to have become sterile on culture with the pus count within the normal range, while the antibody titre increased in both blood and prostatic secretion. In the other two cases the pus count increased, the same organism was isolated by culture, and the prostatic titre remained the same while the blood titre increased. All these ten patients were infected with penicillin resistant staphylococci.

From the results of this follow-up, we may conclude that antibodies produced in the prostate may have a definite role in the cure of chronic bacterial prostatitis. Lines of treatment aiming at the improvement of local and general antibody production are therefore to be recommended, especially in view of the increasing incidence of penicillin resistant staphylococci.

\section{Summary}

The investigation of 150 cases of chronic bacterial prostatitis and twenty normal controls has led to the following observations:

(1) The most common infecting organism in chronic bacterial prostatitis is the staphylococcus.

(2) Staphylococcus albus and diphtheroids should not be overlooked in the treatment of this condition.

(3) A high incidence of penicillin resistant staphylococci may be encountered.

(4) Local and general antibody response occurs in infections of the prostate.

(5) The majority of these patients had no evidence of urinary tract infection. This suggests that a route of invasion other than the urinary tract is the main source of infection of the prostate.

Bacteriological cure was associated with a rise in antibodies in the prostatic secretion, but a rise in 
antibodies in the circulating blood was not necessarily associated with bacteriological cure.

The role of Trichomonas vaginalis in chronic prostatitis is discussed.

Only one of the 150 patients showed $N$. gonorrhoeae.

The authors are deeply indebted to Prof. Dr Salah El-Din El-Kholy, Head of Bacteriology Department, and to Prof. Dr Mohammed Abdel Halim El-Okby, Head of the Skin and Venereal Department, for their valuable suggestions and advice.

\section{REFERENCES}

Archer, G. T. L., and Miller, W. S. (1952). J. roy. Army med. Cps, 98, 285.

Barksdale, W. L., and Ghoda, A. (1951). J. Immunol., 66, 395.

Burrows, W., Elliott, M. E., and Havens, I. (1947). $J$. infect. Dis., 81, 261.

Cumming, R. E., and Chittenden, G. E. (1938). J. Urol. (Baltimore), 39, 118.

Davies, A. (1922). Lancet, 2, 1009.

Kabat, E. A., Moore, D. H., and Landow, H. (1942). J. clin. Invest., 21, 571.

Koshland, M. E., and Burrows, W. (1950). J. Immunol., 65,93 .

Kretschmer, H. L., Berkey, H. A., Heckel, N. U., and Ockuly, E. A. (1937). Illinois med. J., 71, 152.

Naylor, G. R. E., and Caldwell, R. A. (1953). J. Hyg. (Lond.), 51, 245.

Nickel, A. C. (1930). J. Urol. (Baltimore), 24, 343.
Pelouze, P. S. (1939). "Gonorrhoea in Male and Female". Saunders, Philadelphia.

Ritter, J. S., and Lippow, C. (1938). J. Urol. (Baltimore), 39, 111 .

Schlesinger, R. W. (1949). J. exp. Med., 89, 491.

Shaheen, Y., Maged, Z., and Maged, A. (1963). J. Egypt. publ. Hlth, Ass., 38, 131.

Stoker, M. G. P., and Marmion, B. P. (1952). J. Hyg. (Lond.), 50, 1.

Tawil, G. S., and El Kholy, S. (1962). Ann. Inst. Pasteur, $102,339$.

Topley, W. W. C., and Wilson, G. S. (1955). "Topley and Wilson's Principles of Bacteriology and Immunity", revised by G. S. Wilson and A. A. Miles, 4th ed., p. 714. Edward Arnold, London.

Van der Hoeden, J. (1936). Ann. Inst. Pasteur, 56, 206.

Wesson, M. B. (1938). J. Urol. (Baltimore), 39, 135.

Zammit, T. (1906). Rep. Comm. Medit. Fev., Pt 4, p. 69. (Cited by Naylor and Caldwell, 1953).

Étude bactériologique et sérologique de malades atteints de prostatite chronique

\section{RÉSUMÉ}

L'étude de 150 cas de prostatite chronique d'origine bactérienne et de 20 personnes non atteintes servant de contrôle a mené aux conclusions suivantes:

(1) L'organisme d'infection le plus courant dans la prostatite chronique d'origine bactérienne est le staphylocoque.

(2) Le staphylocoque blanc et les diphtéroides ne devraient pas être négligés dans le traitement de cet étât. 